\title{
Adverse Effects of Long-Term Oral Corticosteroids in the Department of Dermatology, Antananarivo, Madagascar
}

\author{
Fandresena Arilala Sendrasoa (iD \\ Irina Mamisoa Ranaivo (D) \\ Arifetraniaina Julia Raherivelo \\ Fahafahantsoa Rapelanoro \\ Rabenja \\ Lala Soavina Ramarozatovo \\ Department of Dermatology, Faculty of \\ Medicine, University of Antananarivo, \\ Antananarivo, Madagascar
}

Background: Long-term oral corticosteroids have an important role in dermatological care in Madagascar. However, significant adverse effects have been associated with continuous exposure to oral corticosteroids.

Objective: We aim to assess the adverse effects of long-term corticosteroid therapy in patients seen in the Department of Dermatology at the University Hospital Joseph Raseta Befelatanana Antananarivo (UH/JRB), Madagascar, and to identify the risk factors associated with these adverse effects.

Methods: A cross-sectional study was conducted during 4 months to assess the adverse effects of long-term corticosteroid therapy in patients seen in the Department of Dermatology. Patients treated with oral corticosteroids for more than 3 months were included in our study.

Results: The prevalence of long-term use of oral corticosteroids in the Department of Dermatology of UH/JRB was $34.28 \%$. A total of 51 patients were included and adverse effects occurred in $64.70 \%$ of this population. Repetitive infections and cutaneous adverse reactions were the most frequent adverse effects, in $23.52 \%$ and $11.76 \%$ of cases, respectively. There were no correlations between age, gender, type of disease treated, the molecule used or daily dose and the risk of adverse effects. Patients who received a corticosteroid dose of more than $40 \mathrm{mg}$ daily (longer than 3 months) or a high cumulative dose of corticosteroids had a high risk of adverse effects.

Conclusion: Repetitive infections and cutaneous adverse reactions are the most frequent adverse effects of long-term oral corticosteroid use. Prescribing the lowest effective dose may reduce the risk of these adverse effects. Furthermore, prevention of the adverse effects of corticosteroids through diet, calcium and vitamin D supplementation is strongly recommended during long-term oral corticosteroid therapy.

Keywords: oral corticosteroids, repetitive infections, cutaneous adverse reactions, high dose

\section{Introduction}

Corticosteroids are commonly prescribed for a variety of indications owing to their wide range of effects on the human body. ${ }^{1}$ They possess potent anti-inflammatory, immunomodulatory and antineoplastic properties. ${ }^{2}$ In France, nearly $1 \%$ of the general population and $3 \%$ of people over 70 years receive long-term corticosteroids. ${ }^{3}$ In the USA, nearly $1.2 \%$ of the adult population receive long-term oral corticosteroids. ${ }^{4}$ Glucocorticoids are important in the treatment of many inflammatory, allergic, immunological and malignant disorders; the toxicity of glucocorticoids is one of the commonest causes of iatrogenic illness associated with chronic inflammatory disease,
Correspondence: Fandresena Arilala Sendrasoa

Department of Dermatology, Faculty of Medicine, University of Antananarivo,

Antananarivo, Madagascar

Email nasendrefa@yahoo.fr 
which requires strict monitoring of patients. After several weeks of treatment, $60-80 \%$ of patients report an adverse effect of treatment. ${ }^{4}$ In developed countries, bone-related adverse effects are the most reported, mainly osteoporosis, ${ }^{5}$ whereas in Africa metabolic effects are the most reported. ${ }^{6,7}$ Long-term oral corticosteroids have an important role in dermatological care in Madagascar. Infrequent conditions in developed countries, such as leprosy reactions, are treated with corticosteroids. In Madagascar, no data concerning the adverse effects of long-term oral corticosteroids have been reported. So, we aim to evaluate the prevalence of adverse effects of long-term oral corticosteroids in the Department of Dermatology at University Hospital Joseph Raseta Befelatanana (UH/JRB), and to identify the risk factors associated with the occurrence of these adverse effects.

\section{Methodology}

A cross-sectional study was conducted during 4 months (from June 2019 to September 2019) in the Department of Dermatology, UH/JRB, which is the reference center on Dermatology in Madagascar. Patients treated with oral corticosteroids for more than 3 months were included in our study. The patients were interviewed using a structured questionnaire. Patients who refused to answer the questionnaire were excluded.

\section{Ethical Considerations}

Written informed consent was obtained from the patients prior to study commencement. Patients gave also consent to have their data published. All study procedures were performed in accordance with the Ethics Committee of University Hospital Joseph Raseta Befelatanana, Antananarivo, Madagascar, and conducted in accordance with the Declaration of Helsinki.

\section{Statistical Analysis}

Data were collected in Excel 2010 and analyzed by Epi Info version 7.2.2.6 software. Data were analyzed using Fisher's exact test for differences of categorical variables such as gender, medical history, indications for corticotherapy and type of molecule. Significance was set at $p<0.05$.

\section{Results}

In total, 295 patients were seen in the Department of Dermatology, UH/JRB, during the 4-month study period. Among 60 patients treated with oral corticosteroids for more than 3 months, 51 patients were included, of whom
33 patients presented adverse effects. The mean age was 34.04 years (minimum 4 years; maximum 91 years). No significant correlation was found between age and the risk of adverse effects $(p=0.64)$. A female predominance was noted, with a sex ratio (male/female) of 0.41 in our study. No correlation was found between gender and risk of adverse effects $(p=0.64)$. Corticosteroids were prescribed for 25 patients who presented lupus erythematosus (49\%), 14 patients with leprosy reaction $(27.45 \%)$, eight patients with scleroderma $(15.69 \%)$ and four patients with other skin diseases $(7.84 \%)$.

Prednisone was the molecule used in 44 patients (86.2\% of cases) and prednisolone in seven patients $(13.72 \%)$. Two patients $(3.92 \%)$ received a corticosteroid dose of less than $10 \mathrm{mg}$ per day, 30 patients $(58.88 \%)$ received 10-40 $\mathrm{mg}$ per day, and doses of more than $40 \mathrm{mg}$ daily were reported in 19 patients (37.25\%). Overall, $25 \%$ of patients who received a corticosteroid dose of less than or equal to $40 \mathrm{mg}$ daily presented adverse effects compared with $52.63 \%$ of patients treated with doses of more than $40 \mathrm{mg}$ daily. The median duration of corticosteroid therapy was 13 months (range: 3-48 months). All patients included in the study had received calcium and vitamin D, but potassium supplementation was optional.

In our study, patients who had adverse events were treated concomitantly with hydroxychloroquine in $64.43 \%$ of cases, with anti-leprosy multidrug chemotherapy (dapsone, clofazimine and rifampicin) in $15.15 \%$ of cases and with methotrexate in $15.15 \%$ of cases. The baseline characteristics of the patients included in this study are shown in Table 1.

Among 33 patients (64.70\%) who presented adverse effects of long-term oral corticosteroids, 12 cases $(23.52 \%)$ presented recurrent infections (urinary infection, paronychia, pneumonia and dermatophyte infection). Cutaneous, musculoskeletal, digestive and neuropsychiatric adverse effects were observed in six cases $(11.76 \%)$, four cases $(7.84 \%)$, four cases $(7.84 \%)$ and two cases $(3.92 \%)$, respectively. Hypokalemia was seen in two patients and steroid-induced diabetes was found in three patients who received corticosteroids at doses of more than $20 \mathrm{mg}$ per day. The adverse effects of corticosteroids seen in our patients are listed in Table 2.

\section{Discussion}

Corticosteroids have been shown to be effective in treating dermatological conditions and are currently used as a firstline immunosuppressive therapy. Our study found no 
Table I Baseline Characteristics of Patients Included in the Study

\begin{tabular}{|c|c|c|c|}
\hline Characteristics & $\begin{array}{l}\text { Adverse } \\
\text { Effects + }\end{array}$ & $\begin{array}{l}\text { Adverse } \\
\text { Effects - }\end{array}$ & $p$-Value \\
\hline $\begin{array}{l}\text { Gender } \\
\text { Female } \\
\text { Male }\end{array}$ & $\begin{array}{l}24 \\
9\end{array}$ & $\begin{array}{l}12 \\
6\end{array}$ & 0.64 \\
\hline $\begin{array}{l}\text { Age } \\
\qquad 4 \mid \text { years } \\
>41 \text { years }\end{array}$ & $\begin{array}{l}24 \\
9\end{array}$ & & 0.64 \\
\hline $\begin{array}{l}\text { Medical history } \\
\text { No } \\
\text { Yes }\end{array}$ & $\begin{array}{l}23 \\
12\end{array}$ & $\begin{array}{l}13 \\
3\end{array}$ & 0.25 \\
\hline $\begin{array}{l}\text { Indications } \\
\text { Lupus erythematosus } \\
\text { Leprosy reaction } \\
\text { Scleroderma } \\
\text { Other disease }\end{array}$ & $\begin{array}{l}14 \\
11 \\
5 \\
3\end{array}$ & $\begin{array}{l}12 \\
3 \\
3 \\
0\end{array}$ & 0.24 \\
\hline $\begin{array}{l}\text { Type of molecule } \\
\text { Prednisone } \\
\text { Prednisolone }\end{array}$ & $\begin{array}{l}28 \\
5\end{array}$ & $\begin{array}{l}16 \\
2\end{array}$ & 0.68 \\
\hline $\begin{array}{l}\text { Daily dose } \\
\quad \leq 40 \mathrm{mg} \\
>40 \mathrm{mg}\end{array}$ & $\begin{array}{l}8 \\
10\end{array}$ & $\begin{array}{l}24 \\
9\end{array}$ & 0.04 \\
\hline $\begin{array}{l}\text { Concomitant treatment } \\
\text { No } \\
\text { Yes }\end{array}$ & $\begin{array}{l}2 \\
31\end{array}$ & $\begin{array}{l}16 \\
2\end{array}$ & 2.91 \\
\hline
\end{tabular}

significant correlations between age, gender, indication or type of molecule and risk of adverse effects. However, a significant correlation was found between daily dosage (more than $40 \mathrm{mg}$ ), taking concomitant treatment and the occurrence of adverse effects.

A significant correlation $(p=0.04)$ was found between daily dosage and the risk of adverse effects, and this was more frequent in patients who received a corticosteroid dose of more than $40 \mathrm{mg}$ daily or a high cumulative dose of corticosteroid $(52.63 \%$ of cases). Our result is consistent with results reported by previous authors. Adverse effects depend upon the dose, according to several authors, ${ }^{8,9}$ as well as on a high cumulative dose of corticosteroids. ${ }^{10}$

In our study, $93.93 \%$ of patients who presented adverse effects were receiving concomitant treatment, such as hydroxychloroquine, chloroquine, chemotherapy for leprosy (dapsone, clofazimine and rifampicine) or methotrexate. Rifampicine is a potent inducer of several metabolic enzyme pathways, so it is necessary to increase the
Table 2 Adverse Effects of Corticosteroids

\begin{tabular}{|l|l|}
\hline Type of Adverse Effects & Number of Patients (\%) \\
\hline $\begin{array}{l}\text { Recurrent infection } \\
\text { Pneumonia } \\
\text { Urinary infection } \\
\text { Paronychia }\end{array}$ & $5(15.15 \%)$ \\
\hline Cutaneous & $3(12.12 \%)$ \\
Hirsutism & $3.09 \%)$ \\
\hline $\begin{array}{l}\text { Bullous dermatosis } \\
\text { Dermatophyte infection }\end{array}$ & $2(6.06 \%)$ \\
\hline Pruritus & $2(6.06 \%)$ \\
Musculoskeletal & $\mathrm{I}(3.03 \%)$ \\
\hline Digestive \\
Gastroesophageal reflux \\
$\begin{array}{l}\text { Epigastralgia } \\
\text { Diarrhea } \\
\text { Vomiting and gastritis }\end{array}$ & $4(3.03 \%)$ \\
\hline Neuropsychiatric & $12.12 \%)$ \\
\hline $\begin{array}{l}\text { Insomnia } \\
\text { Mood change }\end{array}$ & $\mathrm{I}(3.03 \%)$ \\
\hline Hypokalemia & $\mathrm{I}(3.03 \%)$ \\
\hline Steroid-induced diabetes & $\mathrm{I}(3.03 \%)$ \\
\hline
\end{tabular}

dose of drugs with hepatic metabolism, such as corticosteroids. ${ }^{11}$ Chloroquine and hydroxychloroquine may induce QT/QTc prolongation. ${ }^{12}$ Hypokalemia induced by corticosteroids could potentiate this cardiotoxicity by decreasing cardiac contractility. However, no patient in our study had cardiovascular adverse effects.

It is common for long-term corticosteroid therapy to lead to bone loss, which is variable from one patient to another. ${ }^{13}$ In our study, $12.12 \%$ of cases had bone-related adverse effects, including $9.09 \%$ with low back pain and $3.03 \%$ with pelvic joint pain with bone demineralization on radiography. Secondary osteoporosis and non-traumatic osteonecrosis are the most common bone adverse effects of long-term corticosteroids. ${ }^{2}$ According to the literature, the risk factor involved in secondary osteoporosis is lower bone mineral density before the use of corticotherapy. Moreover, bone loss is dose dependent and occurs mainly in the first 6 months after initiation of glucocorticoid therapy. The cumulative dose is also related to the severity of bone loss. ${ }^{10}$

Owing to a lack of resources, no diagnosis of bone loss was made in our study, but low back pain and pelvic joint pain in patients are probably related to secondary 
osteoporosis or aseptic osteonecrosis. Our study showed no correlation between bone loss and the daily dose of corticosteroids $(p=0.16)$, and $31.25 \%$ of bone adverse effects appeared during the first 3 months of the treatment. In fact, $76.47 \%$ of patients in our study received regular calcium and vitamin $\mathrm{D}$ with a low-sodium diet. Hajiroussou and Webley showed, in their cohort study, that bone loss is maximal during the first 6 months of treatment ( $12 \%$ of bone loss) and then more limited (2$5 \%$ per year). ${ }^{13}$

In our study, $12.12 \%$ of cases presented digestive side effects such as gastroesophageal reflux, epigastralgia, diarrhea, vomiting and gastritis. A large meta-analysis showed that corticosteroid use was associated with increased risk of gastrointestinal bleeding and perforation for hospitalized patients only, but not for patients in ambulatory care. ${ }^{14}$ The occurrence of peptic ulcer during corticosteroid treatment was low (less than $2 \%$ of patients), but markedly increased in some groups of subjects (those with concomitant intake of NSAIDs or a history of peptic ulcer).

In the present study, $36.37 \%$ of adverse effects were recurrent infections. All of these patients received a daily corticosteroid dose of up to $10 \mathrm{mg}$. It is well known that the immunosuppressant effects of corticosteroids in supraphysiological doses can lead to patients having increased susceptibility to infection, to deterioration in those with existing infections or to activation of latent infection. ${ }^{15}$ The risk of recurrent infection is lower in patients who receive a daily dose of less than $10 \mathrm{mg}$ or a cumulative dose of less than $700 \mathrm{mg} .{ }^{16,17}$

Psychiatric adverse effects, ranging from insomnia to mood changes, were reported in our study; however, no patient had severe psychiatric adverse events. Insomnia, which was maximal at the beginning of corticosteroid treatment, was reported by several patients. ${ }^{18,19}$ In patients in our study, insomnia was rapidly resolved when the daily dose was decreased, so they did not require alternative treatment or cessation of treatment. The patients who had psychiatric side effects were all active smokers; this is consistent with the result reported by Laouar and Makhloufi, who showed that among $78 \%$ of cases with neuropsychiatric adverse effects, $18 \%$ were active smokers. $^{20}$

Cutaneous adverse effects, such as hirsutism and dermatophyte infection, were found in $18.18 \%$ of cases in this study. Corticosteroids can induce many cutaneous adverse effects, such as atrophy, striae, telangiectasia, hypopigmentation and delayed healing. Fardet et al reported, in a cohort study in two centers in France, that hirsutism and corticosteroid-induced acne affected 10$30 \%$ of patients, and $46 \%$ of patients receiving an average dose of $31 \mathrm{mg}$ prednisone over 3 months developed hirsutism, spontaneous ecchymosis or impaired healing. ${ }^{16}$

Six percent of cases presented hypokalemia in our study. In a general review, Gennari reported that kalemia decreased from 0.2 to $0.4 \mathrm{mmol} / \mathrm{L}$ during long-term oral corticosteroid therapy. ${ }^{21}$ The correlation between corticosteroids and hypokalemia is ambiguous. Few studies have reported an association between corticotherapy and hypokalemia. $^{22}$

Steroid-induced diabetes was found in three patients who received corticosteroids at a dose of more than $20 \mathrm{mg}$ per day. The exact prevalence of hyperglycemia secondary to glucocorticoid therapy is not known, making this an unpredictable challenge for general practitioners and endocrinologists alike. ${ }^{23,24}$ A 2014 meta-analysis indicated that the rates of glucocorticoid-induced hyperglycemia and diabetes were $32.3 \%$ and $18.6 \%$, respectively. ${ }^{25}$ The probable risk factors for corticosteroid-induced diabetes are older age, higher glycosylated hemoglobin $\left(\mathrm{HbA}_{1 \mathrm{c}}\right)$ level and lower estimated glomerular filtration rate (eGFR). ${ }^{26}$ Some studies reported that the dose of glucocorticoid was not statistically significantly related to the development of steroid-induced diabetes. ${ }^{26,27}$

\section{Conclusion}

The use of long-term oral corticosteroids is common in dermatology. Our study shows that there were no correlations between age, gender, type of disease treated and the molecule used, daily dose and the risk of adverse effects. Patients who received a corticosteroid dosage of more than $40 \mathrm{mg}$ daily or a high cumulative dose of corticosteroid had a high risk of adverse effects. Our study has a limitation, in that only patients seen in the Department of Dermatology in the UH/JRB were included, resulting in a small sample size.

\section{Disclosure}

The authors report no conflicts of interest in this work.

\section{References}

1. Kapugi M, Cunningham K. Corticosteroids. Orthop Nurs. 2019;38 (5):336-339. doi:10.1097/NOR.0000000000000595 
2. Rice JB, White AG, Scarpati LM, Wan G, Nelson WW. Long-term systemic corticosteroid exposure: a systemic literature review. Clin Ther. 2017;39:2216-2229. doi:10.1016/j.clinthera.2017.09.011

3. Chemical Book. Hydrocortisone (50-23-7); 2008. Available from: http://www.chemicalbook.com/ProdSupplierGNCB9756715_EN. htm. Accessed January 30, 2014.

4. Fardet L, Kassar A, Cabane J, Flahault A. Corticosteroid induced adverse events in adults: frequency, screening and prevention. Drug Safety. 2007;30(10):861-881. doi:10.2165/00002018-200730100-00005

5. Kok C, Sambrook PN. Secondary osteoporosis in patients with an osteoporotic fracture. Best Pract Res Clin Rheumatol. 2009;23:769-779. doi:10.1016/j.berh.2009.09.006

6. Nassar K, Janani S, Roux C, Rachidi W, Etaouil N, Mkinsi O. La corticothérapie systémique au long cours: representations des patients, perceptions des prescripteurs et observance thérapeutique [Long-term systemic glucocorticoid therapy: patient's representations, prescriber's perceptions, and treatment adherence]. Rev Rhum. 2014;81(1):49-53. doi:10.1016/j.rhum.2013.04.008

7. Zomalheto Z, Dossou-yovo H, Zossoungbo F, Avimadjè M. Prévalence des complications de la corticothérapie chez les sujets ouest-africains consultant en rhumatologie[Prevalence of complications of corticosteroid therapy among West African consulting in rheumatology]. PAMJ. 2015;21:304. doi:10.11604/pamj.2015.21.304. 5805

8. Dubois EF, Roder R, Dekhuijzen PN, Zwinderman AE, Schweitzer DH. Dual energy X-ray absorptiometry outcomes in male COPD patients after treatment with different glucocorticoid regimens. Chest. 2002;121:1456-1463. doi:10.1378/chest.121.5.1456

9. Lefebvre P, Duh MS, Lafeuille MH, et al. Acute and chronic systemic corticosteroid-related complications in patients with severe asthma. $J$ Allergy Clin Immunol. 2015;136:1488-1495. doi:10.1016/j. jaci.2015.07.046

10. Van Staa TP, Leufkens HG, Abenhaim L, Zhang B, Cooper C. Oral corticosteroids and fracture risk: relationship to daily and cumulative doses. Rheumatology. 2000;39:1383-1389. doi:10.1093/rheumatology/ 39.12.1383

11. Fiches modèles OMS d'information à l'usage des prescripteurs: médicaments utilisés dans les mycobactérioses[WHO model prescribing information: drugs used in mycobacteral diseases]; 1993. Available from: https://apps.who.int/medicinedocs/en/d/ Js5512f/4.1.html. Accessed September 13, 2021.

12. Roden DM. Predicting drug-induced QT prolongation and torsade de pointes. J Physiol. 2016;594:2459-2468. doi:10.1113/JP270526

13. Hajiroussou VJ, Webley M. Prolonged low-dose corticosteroid therapy and osteoporosis in rheumatoid arthritis. Ann Rheum Dis. 1984;43(1):24-27. doi:10.1136/ard.43.1.24

14. Narum S, Westergren T, Klemp M. Corticosteroids and riskof gastrointestinal bleeding: a systematic review and meta-analysis. $B M J$ Open. 2014. 4. e004587.
15. Martindale. The complete drug reference. Accessed through medicines complete. Available from: https://www.medicinescomplete. com/mc/martindale/current/1060-a2-n.htm. Accessed September 13, 2021.

16. Fardet L, Flahault A, Kettaneh A, et al. Corticosteroid-induced clinical adverse events: frequency, risk factors and patient's opinion. $\mathrm{Br}$ $J$ Dermatol. 2007;157(1):142-148. doi:10.1111/j.1365-2133.2007. 07950.x

17. Hoes JN, Jacobs JW, Verstappen SM, Bijlsma JW, Van der Heijden GJ. Adverse events of low- to medium-dose oral glucocorticoids in inflammatory diseases: a meta-analysis. Ann Rheum Dis. 2009;68:1833-1838. doi:10.1136/ard.2008.100008

18. Warrington TP, Bostwick JM. Psychiatric adverse effects of corticosteroids. Mayo Clin Proc. 2006;81(10):1361-1367. doi:10.4065/81.10.1361

19. Kenna HA, Poon AW, de Los Angeles CP, Koran LM. Psychiatric complications of treatment with corticosteroids: review with case report. Psychiatry Clin Neurosci. 2011;65:549-560. doi:10.1111/ j.1440-1819.2011.02260.x

20. Laouar L, Makhloufi M. Les troubles neuropsychiatriques et corticothérapie systémique[Neuropsychiatric disorders and systemic corticosteroids in 72 patients]. Rev Mal Resp. 2016;33:A121-22. doi:10.1016/j.rmr.2015.10.206

21. Gennari FJ. Hypokaliemia. $N$ Engl J Med. 1998;339(7):451-458. doi:10.1056/NEJM199808133390707

22. Roshni PR, Saikeerthana PC, Krishna PR. Steroid induced hypokalemia: a case report. J Pharm Sci Rev Res. 2017;42(1):42-43.

23. Mills E, Devendra S. Steroid-induced hyperglycaemia in primary care. London J Prim Care (Abingdon). 2015;7:103-106. doi:10.1080/17571472.2015.1082344

24. van Raalte DH, van Genugten RE, Linssen MM, Ouwens DM, Diamant M. Glucagon-like peptide-1 receptor agonist treatment prevents glucocorticoid-induced glucose intolerance and islet-cell dysfunction in humans. Diabetes Care. 2011;34:412-417. doi:10.2337/dc10-1677

25. Liu XX, Zhu XM, Miao Q, Ye HY, Zhang ZY, Li YM. Hyperglycemia induced by glucocorticoids in nondiabetic patients: a meta-analysis. Ann Nutr Metab. 2014;65:324-332. doi:10.1159/ 000365892

26. Katsuyama T, Sada KE, Namba S, et al. Risk factors for the development of glucocorticoid-induced diabetes mellitus. Diabetes Res Clin Pract. 2015;108(2):273-279. doi:10.1016/j.diabres.2015.02.010

27. Kim SY, Yoo C-G, Lee CT, et al. Incidence and risk factors of steroid-induced diabetes in patients with respiratory disease. J Korean Med Sci. 2011;26(2):264-267. doi:10.3346/jkms.2011.26.2.264
Clinical, Cosmetic and Investigational Dermatology

\section{Publish your work in this journal}

Clinical, Cosmetic and Investigational Dermatology is an international, peer-reviewed, open access, online journal that focuses on the latest clinical and experimental research in all aspects of skin disease and cosmetic interventions. This journal is indexed on CAS.
The manuscript management system is completely online and includes a very quick and fair peer-review system, which is all easy to use. Visit http://www.dovepress.com/testimonials.php to read real quotes from published authors. 